\title{
Clean milk production practices and its impact on the prevention and control of mastitis in Tiruchirapalli district of Tamil Nadu
}

\author{
G. Rajarajan \\ Received: 15 May 2020 / Accepted: 13 August 2020 / Published online: 27 October 2020 \\ (C) Indian Dairy Association (India) 2020
}

\begin{abstract}
Mastitis is one of the major infectious diseases affecting dairy cows and causing economic loss. Majority of the rural dairy farmers are not aware of preventing mastitis through management practices. Lack of adoption of clean milk production practices is the major reason for mastitis. So the focus of study was imparting knowledge on clean milk production practices to dairy farmers from selected villages in Tiruchirapalli district along with management of mastitis in dairy animals through capacity building programme. After the adoption of clean milk production practices, there was remarkable reduction in the incidence of mastitis from 19.33 per cent to 2.4 per cent. The keeping quality of milk was also improved by enhancement in methylene blue dye reduction time (MBRT). This was an indirect indication of improved microbial quality of raw milk. The subclinical mastitis was monitored with somatic cell count (SCC) and the quarters of udder health by California mastitis test (CMT) respectively. The mastitic animal was treated effectively with suitable antibiotic by conducting antibiotic sensitivity test (ABST) and thereby protected the dairy farmers from huge economic loss.
\end{abstract}

Keywords: Capacity building, Clean milk production, Mastitis, Prevention, Control

\section{Introduction}

The bovine Mastitis is an economically important disease in lactating animals across the world followed by lameness and

G. Rajarajan $(\bowtie)$

Department of Livestock Products Technology

Veterinary College and Research Institute, Oratahanadu- 614625 Thanjavur District

Tamil Nadu Veterinary Animal Sciences University, Tamil Nadu, India

Email: G.Rajarajan-rajarajanvet@gmail.com infertility under field condition and causes considerable financial losses to Dairy industry (Green et al, 2004). The annual economic loss due to mastitis has been calculated to be Rs. 7165.51 crores. Among this, subclinical mastitis has been estimated to account for 57.93 percent ( 4151.16 crores) of the total economic loss due to mastitis (NAAS, 2013).

Mastitis severely affects the milk quality and production of the cow and may spread to other cows in the herd. Deterioration of milk quality is a major sequel of Mastitis. Mastitis is characterized by inflammation of udder tissue causing pathological changes in udder parenchyma and characterized by physical, chemical and microbiological changes in milk (Radostitis et.al, 2000). Further, the mastitic milk is unsuitable for consumption and is one of sources of communicable diseases such as tuberculosis, brucellosis, staphylococcal toxemia, septic sore throat, gastroenteritis, etc., (Kalorey., 2001). Although notable progress has been made in prevention of mastitis by appropriate hygienic measures, enhanced control of milking techniques and antibiotic treatment of dry cow, but it is still necessary to treat a large number of cows which suffer from mastitis. The multiplicity of the cause and emergence of indiscriminate and prolonged use of antibiotics in absence of antibiogram is a major hurdle in the control of mastitis (Mathialagan and Kumaresan, 2015).

Hence, the proposed study is aimed to impart knowledge on clean milk production practices to dairy farmers through capacity building programme which will create awareness about subclinical, clinical mastitis, prevention and management of mastitis in dairy animals. The dairy cows suffering from mastitis are going to be treated with suitable antibiotics based on Antibiotic Sensitivity Test (ABST) so that the trained beneficiaries will be protected from huge economic loss by improving the raw milk quality.

\section{Materials and Methods}

\section{Study area}

The study was conducted in Tiruchirapalli district of Tamil Nadu. Three blocks which have recorded maximum numbers of case of mastitis were identified viz. Andhanallur, Mannachanallur and 
Manikandam, from the endemic record maintained at Animal Disease Intelligence Unit, Tiruchirapalli. Four villages from each block, totally twelve villages were selected for this field study. Fifty dairy farmers from each village, constitute a total of six hundred beneficiaries were selected on the basis of having at least two dairy animals out of which one should be in lactation.

\section{Capacity building programme}

The two day capacity building programme included both on farm and institutional training programme at TANUVAS-Veterinary University Training and Research Centre, Tiruchirapalli for the dairy farmers on clean milk production practices and the demonstrations on cleaning of dairy cattle, disinfection and sanitation of shed, milking methods, cleaning of udder, post teat dipping, strip cup test-mastitis detection were also conducted. Inputs like mastitis detection kit, post-teat dip container, povidone iodine, plastic hand sprayer, potassium permanganate, plastic bottles, test tubes for milk sample collection and reading materials in local vernacular were distributed to all the beneficiaries.

\section{Assessment of raw milk quality and detection of mastitis}

The Methylene Blue dye Reduction Test (MBRT) was performed in dairy farm since it is a quick method for determining the bacterial load, sanitary condition and keeping quality of milk. The test also indicates the hygienic condition of milk during its production and handling.

The most significant abnormality found in milk due to subclinical mastitis is the increase in Somatic cell count (SCC). Since cell numbers in milk are closely associated with inflammation of udder health, these somatic cell counts currently constitute an important criterion for the measurement of milk quality as an international standard (Hillerton, 1999). The milk from suspected animals were collected and examined for somatic cells count using Ekomilk Horizon Milk Analyzer.

The California Mastitis Test (CMT) was extremely used to identify the specific quarters infected with clinical and subclinical mastitis. The test was conducted on a white plastic paddle with four cups corresponding to four teats. Milk from each teat is flown directly into the cups and equal amount of reagent added along with bromocresol purple as an indicator. The positive case revealed gel formation and in negative case there was no precipitation (Sandholm, 1995).

\section{Antibiotic Sensitivity Test}

The milk sample from suspected mastitis animals were collected aseptically and sent to the laboratory at Veterinary University Training and Research Centre, Tiruchirapalli for antibiotic sensitivity test using Muller-Hinton agar plates and Antimicrobial sensitivity discs. Based on zone of inhibition, suitable antibiotic therapy was suggested by the specialists to cure the animal suffering from mastitis (Erskine et al, 2003).

A teacher made knowledge test was developed in a simple vernacular language and the same was employed thrice viz., before training, immediately after training and 90 days after training to assess their retention of knowledge learned during the training. The enhancement in the knowledge level is the difference between knowledge retention score and the pre-training knowledge score. A semi-structured interview schedule was prepared and employed for data collection. Descriptive statistics were employed to interpret the findings.

\section{Results and Discussion}

\section{Status of clean milk production at field level}

\section{General Cleanliness}

Table 1 shows that 75.83 per cent of respondents were cleaning their cattle shed daily. Similarly, 60.00 per cent of them were cleaning their dairy cows daily. Most of the respondents were cleaning their milch cows ranged from daily basis to five days interval. Each and every respondent was cleaning the milk utensils before milking. These findings were in accordance with Gautam and Mohammad, 2019.

\section{Clean milk production practices}

The Pre-exposure and post-exposure knowledge tests were conducted to all the 600 beneficiaries focusing on the objectives of clean milk production before the commencement and immediately after completing the training programme. The retention level of gained knowledge was tested 90 days after the completion of capacity building programme.

Table 2 shows that only 5.33 per cent the dairy farmers were following the practice of Cleaning of udder with potassium permanganate solution before milking. In contrast, Patel et al. (2014) revealed that splashing of water on udder or teats and washing of hand before milking was followed by most (97.50\%). After washing the udder, around 4.33 percent wipe it with clean cloth. Only 8.17 per cent knew that cleaning of hands of milkman before milking was important. Patil et al. (2009) also suggested that majority of the dairy farmers did not know that the milker should be healthy and free from bad habits. This might be because of their ignorance about milker's personal hygiene and spreading of zoonotic diseases through human.

There are various types of cleaning and sanitation agents that have been specially designed to clean and disinfect milk-handling equipment (Lore et al. 2006). The study revealed that only 12.17 per cent were practised cleaning agent for milking utensils. Few respondents $(10.83 \%)$ were sun drying their utensil after cleaning and most of them were not practicing the same. Majority of the 
respondents were not giving concentrate feed at the time of milking except 2.5 per cent.

Full hand milking method was practiced by 15.33 per cent and majority them 84.67 per cent preferred stripping and knuckling method of milking, because of small size of their animal's teats and shorter milking time. Similar finding of high rate of Knuckling practice (74.4\%) was also reported by Sinha et al. (2010). A very few dairy farmers $(1.83 \%)$ had knowledge regarding knuckling method leads to teat injury. Post teat dipping with Iodine solution was practiced only by two dairymen out of six hundred.

Not even a single dairy farmer had the knowledge regarding animal should stand for 15-20 minutes after milking so that teat canal gets closed and the soil bacteria could not enter teat canal which leads to mastitis. Nearly half of the famers $(47.67 \%)$ were providing roughage feeding material to their animals and rest of the respondents were not even conscious about the benefits of providing roughages to animals since it made the animal to stand for half an hour and during that time teat canal got closed.
Usage of sieve during transfer of milk from one can to another was practiced moderately by 37.17 per cent and rest were not aware that sieve could prevent the entry of dirt and extraneous matter. Only (16\%) were used steel utensil for milking purpose and remaining $(84 \%)$ were using plastic or aluminium cans or brass utensils. Out of 600 respondents only four persons were able to detect subclinical mastitis by making milk strip in their hand palm and examined with taste buds, revealed sour taste since chloride content was more in subclinical mastitis.

During this project, we have encountered only seventeen (2.83\%) well informed farmers who employed milking machine in their farm. The majority of the dairy farmers were told that milking machine was costlier and it could cause damage to udder. But in practical, milking machine is safe and faster and convenient when compare to human hand milking as it minimize milk contamination through milker and at the same time cleaning and maintenance also simple. Nowadays, Government subsidy is available in some states and farmers can make use of it and avoid dependency of milkman.

Table 1 General cleanliness of dairy farm $(n=600)$

\begin{tabular}{lllllc}
\hline S. no. & Parameter & $\begin{array}{l}\text { Daily } \\
(\%)\end{array}$ & $\begin{array}{l}2 \text { days interval } \\
(\%)\end{array}$ & $\begin{array}{l}5 \text { days interval } \\
(\%)\end{array}$ & $\begin{array}{c}\text { More than } \\
\text { week }(\%)\end{array}$ \\
\hline 1. & Cleaning of cattle shed & $455(75.83)$ & $140(23.33)$ & $5(0.83)$ & 0 \\
2. & Cleaning of dairy cow & $360(60.00)$ & $125(20.83)$ & $115(19.17)$ & 0 \\
3. & Cleaning of milking utensils $600(100.00)$ & 0 & 0 & 0 \\
\hline
\end{tabular}

Table 2 Knowledge level of dairy farmers on clean milk production practices $(n=600)$

\begin{tabular}{|c|c|c|c|c|}
\hline S.No. & Technologies / practices & $\begin{array}{l}\text { Pre-exposure }(\%) \\
\text { adoption }\end{array}$ & $\begin{array}{l}\text { Post-exposure }(\%) \\
\text { knowledge }\end{array}$ & $\begin{array}{l}\text { Retention }(\%) \\
\text { of knowledge }\end{array}$ \\
\hline$\overline{1}$ & $\begin{array}{l}\text { Cleaning of udder with Potassium } \\
\text { permanganate solution before milking }\end{array}$ & $32(5.33)$ & $535(89.17)$ & $485(80.83)$ \\
\hline 2 & Wiping the udder with clean cloth & $26(4.33)$ & $502(83.67)$ & 433(72.17) \\
\hline 3 & Cleaning of milkman hands before milking & $49(8.17)$ & $514(85.67)$ & $449(74.83)$ \\
\hline 4 & Usage of cleaning agent for utensils & $73(12.17)$ & $547(91.17)$ & $496(82.67)$ \\
\hline 5 & Sun drying of utensil after cleaning & $65(10.83)$ & $529(88.17)$ & $471(78.50)$ \\
\hline 6 & $\begin{array}{l}\text { Providing concentrate to animal during } \\
\text { milking }\end{array}$ & $15(2.50)$ & $510(85.00)$ & $478(79.67)$ \\
\hline 7 & Knowledge of Full hand milking method & $92(15.33)$ & $524(87.33)$ & $469(78.17)$ \\
\hline 8 & $\begin{array}{l}\text { Knowledge regarding Knuckling method } \\
\text { leads to teat injury }\end{array}$ & $11(1.83)$ & $547(91.17)$ & $493(82.17)$ \\
\hline 9. & Post teat dipping with Iodine olution & $2(0.33)$ & $538(89.67)$ & $476(79.33)$ \\
\hline 10. & $\begin{array}{l}\text { Knowledge regarding animal should } \\
\text { stand for } 15-20 \text { minutes after } \\
\text { milking so that teat canal gets closed }\end{array}$ & $0(0.00)$ & $501(83.50)$ & $482(80.33)$ \\
\hline 11. & Provision of roughages after milking & $286(47.67)$ & $559(93.17)$ & $502(83.67)$ \\
\hline 12. & $\begin{array}{l}\text { Usage of sieve during transfer of } \\
\text { milk from one can to another }\end{array}$ & $223(37.17)$ & $543(90.50)$ & $498(83.00)$ \\
\hline 13. & $\begin{array}{l}\text { Usage of stainless steel utensils for } \\
\text { milking purpose }\end{array}$ & $96(16.00)$ & $526(87.67)$ & $487(81.17)$ \\
\hline 14. & Detection of subclinical mastitis & $4(0.67)$ & $510(85.00)$ & $473(78.83)$ \\
\hline 15. & Usage of milking machine & $17(2.83)$ & $508(84.67)$ & $462(77.00)$ \\
\hline
\end{tabular}




\section{Constraints faced by the dairy farmers pertaining to mastitis}

The results of Table 3 revealed that only 5.33 per cent of the dairy farmers were aware of mastitis prevention methods and none of them were aware about subclinical mastitis detection test. The dairy farmers revealed that if a cow was affected with mastitis, they had to spend more money for the treatment because it was costlier $(83.50 \%)$. They also perceived that most of the time the animal was not responded to treatment $(77.17 \%)$ and if the mastitis was not cured, then the particular quarter could become dormant $(31.17 \%)$, thereby they used to get huge economic loss $(90.33 \%)$. Similar results were reported by Byarugana et al. (2008) and also Mathialagan and Kumaresan (2015) who stated that none of the dairy farmers knew about subclinical mastitis and most of them considered mastitis was a major constraint for wealth creation through milk production.

\section{Impact of clean milk production training on incidence of mastitis and raw milk quality}

The analysis of benchmark survey revealed that $116(19.33 \%)$ of the beneficiaries had faced the problem of mastitis and the same has been controlled through the implementation of the project. Table 4 shows the impact of the adoption of mastitis detection and prevention technique as perceived by the scheme beneficiaries. The beneficiaries reported that there was a drastic reduction in the occurrence of mastitis cases from 19.33 per cent to a level of 2.4 per cent after adoption of the mastitis detection, prevention and control techniques. This indicates that the mastitis prevention and control training methodology was highly effective. Riekerink et al. (2010) reported that most of Canadian dairy farms adopted important mastitis prevention practices such as clean milk production practices since mastitis was highly related to farm management activities.

Interestingly, the keeping quality of raw milk was also improved by increase in Methylene blue dye reduction time (MBRT) from 2-3 hours to $4-5$ hours. This is an indirect indication of improved microbial quality of raw milk.

Sub clinical mastitis is characterized by increase in Somatic cell count without any observable changes in milk and udder and it is a chief cause of heavy monetary losses to dairy farming (Jadav et al. 2010).The original limit for Somatic cell count of a healthy quarter as suggested by the International Dairy Federation is 5,00,000 cells per ml (Jadhav et al. 2013) From Table 4, the microscopic examination of the milk samples revealed that there was significant reduction in the somatic cell count

Table 3 Constraints faced by the dairy farmers pertaining mastitis $(n=600)$

\begin{tabular}{llc}
\hline S.No. & Constraints & Yes (\%) \\
1 & Not aware of the subclinical mastitis detection test & $596(99.33)$ \\
2 & Treatment is costly & $501(83.50)$ \\
3 & Lack of training on mastitis prevention methods & $568(94.67)$ \\
4 & Animal not responded to treatment & $463(77.17)$ \\
5 & Awareness that affected quarter becomes dormant & $187(31.17)$ \\
6 & Heavy economic loss & $542(90.33)$ \\
\hline
\end{tabular}

Table 4 Impact of training on incidence of mastitis and raw milk quality

\begin{tabular}{cccccccc}
\hline $\begin{array}{c}\text { Incidence of mastitis in Methylene Blue dye Reduction } \\
\text { milch cows }\end{array}$ & \multicolumn{2}{c}{ Test (MBRT) $\mathrm{n}=86$} & \multicolumn{2}{c}{$\begin{array}{c}\text { Somatic Cell } \\
\text { Count (SCC) } \\
\mathrm{n}=86\end{array}$} & \multicolumn{2}{c}{$\begin{array}{c}\text { California } \\
\text { Mastitis Test (CMT) } \\
\mathrm{n}=61\end{array}$} \\
\hline $\begin{array}{c}\text { Before } \\
\text { adoption }\end{array}$ & $\begin{array}{c}\text { After } \\
\text { adoption }\end{array}$ & $\begin{array}{c}\text { Before } \\
\text { adoption } \\
\text { hours }\end{array}$ & After adoption & $\begin{array}{c}\text { Before } \\
\text { adoption } \\
\text { lakhs /ml }\end{array}$ & $\begin{array}{c}\text { After } \\
\text { adoption }\end{array}$ & $\begin{array}{c}\text { Fore quarter } \\
\text { mastitis }\end{array}$ & $\begin{array}{c}\text { Hind quarter } \\
\text { mastitis }\end{array}$ \\
\hline $\begin{array}{c}116 \\
(19.33 \%)\end{array}$ & $\begin{array}{c}14 \\
(2.4 \%)\end{array}$ & $2-3$ & $4-5$ & $6-8$ & $4-5$ & $23(37.7)$ & $38(62.3)$ \\
\hline
\end{tabular}

Table 5 Sensitivity of antibiotics towards mastitis organism based on ABST ( $\mathrm{n}=14)$

\begin{tabular}{llllllc}
\hline $\begin{array}{l}\text { Type of } \\
\text { reaction }\end{array}$ & Enrofloxacin & Tetracycline & Gentamicin & $\begin{array}{l}\text { Cipro } \\
\text { floxacin }\end{array}$ & Penicillin & Cephalosporin \\
\hline Sensitivity & 9 & 12 & 13 & 10 & 7 & 11 \\
Resistance & 5 & 2 & 1 & 4 & 7 & 3 \\
Sensitivity(\%) & 64.28 & 85.71 & 92.85 & 71.42 & 50.0 & 78.57 \\
\hline
\end{tabular}


after implementing clean milk production strategies in dairy farm.

The California mastitis test is used to identify the specific udder quarter infected with clinical and sub clinical intra-mammary infection and is an indicator of mastitis as well as heard monitoring programme (De, 2010). The present study revealed that around 62.3 per cent of mastitis was diagnosed in hind quarters and 37.7 per cent in fore quarters of udder.

\section{Sensitivity of antibiotics towards mastitis organism based on ABST}

The dairy farmers were started to follow the clean milk production practices after the training programme which eventually leads to reduction in the incidence of mastitis from 116 to 14 during the one year period of study. Table 5 shows the antibiotic sensitivity pattern of infected milk samples. The results indicated that the mastitic pathogens were sensitive to Gentamicin, Tetracycline, Cephalosporin, Ciprofloxacin, Enrofloxacin and Penicillin as descending order of sensitivity. These results were communicated to the training beneficiaries and the concerned veterinarians who have treated the affected animals. The affected cows were treated at the earliest with specific antibiotic based on antibiogram and thereby saved the farmers from huge economic loss.

\section{Conclusions}

The capacity building programme was conducted in the selected villages pertaining to clean milk production practices which had great impact in reduced incidence of mastitis in dairy cattle. The dairy farmers were trained on mastitis detection and inputs were supplied for the detection of mastitis in the initial stage itself. The keeping quality of raw milk was improved with enhanced methylene dye reduction time. There was also considerable reduction in the somatic cell count in raw milk by the adoption of clean milk production practices and it was an indirect indication of improved microbial quality of raw milk. The study revealed that there was a drastic reduction in the occurrence of mastitis cases from 19.33 per cent to 2.4 per cent after adopting knowledge and skills on the mastitis detection and control techniques. The affected animals were treated with suitable antibiotic based on Antibiotic Sensitivity Test and saved the dairy farmers from economic loss. It was concluded that imparting knowledge on clean milk production practices to dairy farmers will eventually lead to prevention and control of mastitis under field condition.

\section{Acknowledgement}

The author expresses his gratitude to Tamil Nadu Veterinary and Animal Sciences University, Chennai for financial support under TANUVAS-Research Corpus Fund scheme.

\section{References}

Byarugaba DK, Nakavuma, JL, Vaarst M, Laker C (2008) Mastitis occurrence and constraints to mastitis control in smallholder dairy farming systems in Uganda. Livest Res Rural Dev 20, Article \#5. Retrieved April 27, 2020, from http://www.lrrd.org/lrrd20/1/ byar20005.htm

De UK (2010) Diagnosis of bovine mastitis. Indian Dairyman66-73

Erskine RJ, Wagner S, De Graves FJ (2003) Mastitis therapy and Pharmacology. Vet Clin Food Anim 19: 109-138

Gautam PK, Mohammad A (2019) Deciphering the efficacy of multimedia based intervention for augmenting knowledge status: a clean milk production perspective. Indian J Dairy Sci 72: 422-429

Green MJ, Green LE, Schukken YH, Bradley AJ, Peeler EJ, Barkema HW, Haas YD, Collis VJ, Medley GF (2004) Somatic cell count distributions during lactation predict clinical mastitis. J Dairy Sci 87: $1256-1264$

Hillerton JE (1999) Redefining mastitis based on somatic cell count.IDF Bulletin 345:4-6

Jadhav P, Tarate S, Das DN, Shome BR (2013) Milk somatic cells: Indian scenario in global context. Indian Dairyman 62-65

Jadhav RK, Singh VK, Bhosale RA (2010) Successful management of bovine mastitis. Indian Dairyman 68-73

Kalorey DR (2001) Future prospects for mastitis control. In: Proceedings of VIII Annual Conference of Indian Association for the advancement of Veterinary Research held at Ludhiana, 81-85

Lore TA, Kurwijila LR, Omore A (2006) Hygienic milk production: a training guide for farm-level workers and milk handlers in Eastern Africa. Nairobi (Kenya): ILRI (International Livestock Research Institute), Nairobi, Kenya, 1-12

Mathialagan P, Kumaresan G (2015) Farm women participatory On-Farm Trial (OFT)

on Prevention and Control of Mastitis in Dairy Cattle. Indian J Vet Anim Sci Res 44: 110-115

NAAS (2013Mastitis Management in Dairy Animals. Policy Paper No. 61, National Academy of Agricultural Sciences, New Delhi, pp5

Patel NB, Kavad SD, Rao TKS (2014) Eco-friendly livestock management practices followed by tribal households of Narmada valley region of India. J Appl Nat Sci 6: 512-518

Patil AP, Gawande SH, Nande MP, Gobade MR (2009) Assessment of knowledge level of dairy farmers in Nagpur district and the corelation between socio-economic variables with their training needs. Vet World 2: 199-201

Radostitis OM, Gay CC, Blood DC, Funchcliff K (2000) Veterinary medicine: A text book of the disease of cattle, sheep, goat, horse and pigs. 9th edn. W.B.Saunders, London

Riekerink RG, Barkema HW, Scholl DT, Poole DE, Kelton DF (2010) Management practices associated with the bulk-milk prevalence of Staphylococcus aureus in Canadian dairy farms. Pre Vet Med 97: 20-28

Sandholm M (1995) Detection of inflammatory changes in the milk, In: Sandholm M, Honkanen-Buzalski T, Kaartinen L, Pyorala S (eds) The bovine udder and mastitis, Gummerus, Jyvaskyla, Finland pp 89-104

Sinha RRK, Dutt TS, Bhusan BRR, Singh M, Kumar S (2010) Comparative studies of calf rearing and milking management practices in rural, semi-urban and urban areas of Bareilly district of Uttar Pradesh. Indian J Anim Sci 80: 483-485 